\title{
O VERDADEIRO SIGNIFICADO DO "ESTADO DO BRASIL" E AS BASES DINÁSTICAS DE NOSSA UNIDADE NACIONAL.
}

Instalada a Côrte portuguêsa no Rio de Janeiro, após sua chegada aqui em 8 de março de 1808, e reorganizada tôda a sua máquina governamental, automàticamente transformara-se a antiga sede administrativa dos vice-reis do Brasil em centro de tôdas as prerrogativas da monarquia absolutista bragantina. Como todo o poder ainda emanava exclusivamente da própria pessoa do soberano efetivamente reinante, sua moradia obrigatòriamente se identificaria sempre com a sede governamental e administrativa de todos os seus domínios, tanto metropolitanos como ultramarinos. Onde se encontrasse pois Dona Maria I (1734-1816), rainha de Portugal e Algarves, representada em seu impedimento mental desde 10 de fevereiro de 1792 pelo respectivo filho e herdeiro legítimo, o futuro D. João VI (1767-1826), aí estaria sempre a sede do poder soberano, sem restrições.

Numa monarquia absoluta, ao menos até 1820 , quando uma inssurreição político-militar implantaria em Portugal o regime constitucional que a derrogaria e que obrigaria à Côrte ao regresso para Lisboa, não precisavam os soberanos da casa de Bragança recorrer a atos para legitimar o deslocamento da mesma Côrte para uma ou outra parte de seus domínios efetivos. Um ato como êste significaria pura e simplesmente como que o aceite de uma delimitação dos próprios poderes absolutistas institucionais perante a coletividade monárquica de seus súditos, animando-os a esperar e mesmo a exigir parte daquilo que iriam impor depois de 1820. Não precisava, pois, o futuro D. João VI publicar decreto ou ato algum para legalizar sua transferência de domicílio normal metropolitano sob a pressão das armas invasoras franco-napoleônicas ao comando do marechal Andoche Junot (1771-1813), com ameaça de um aprisionamento de tôda família real. Um monarca absoluto sòmente se poderia curvar, ao menos teòricamente, aos preceitos divinos e ante aquilo que sua consciência julgasse do interêsse de sua dinastia ou mesmo do "interêsse público" de seu reino, ou que sua prudência 
aceitasse frente à alguma rebelião interna vitoriosa, além do caso em foco, isto é, numa guerra infeliz como a de então.

Existe apenas um decreto relativo ao assunto, aquêle de 26 de novembro de 1807 , proclamado às vésperas do embarque tumultuoso para o Brasil e firmado ainda no palácio de Nossa Senhora de Ajuda, com $\circ$ que o então príncipe-regente português nomeava um conselho de regência para o "Govêrno dêstes Reinos", de acôrdo com instruções especiais da mesma data, comunicando oficialmente que iria ausentar-se "dêste Reino", passando, "para os Estados da América" a estabelecer-se "na cidade do Rio de Janeiro até a paz geral" (1).

Sua presença soberana no Rio de Janeiro, centralizando aí todos os poderes emanados de sua pessoa, desviou logo para a nova capital todo o movimento burocrático que antes se achava orientado diretamente para Lisboa. Surgiria, assim, automàticamente uma unidade administrativa, judiciária e militar que nunca existira no território pretensamente denominado de "Estado do Brasil", desde o rio Oiapoque até ao arrôio Chuí. E' que numa monarquia absoluta como a portuguêsa de então, salvo naquilo que já se reconhecia para a metrópole através de velhos usos e costumes, tàcitamente aceitos, e que fizeram com que fôsse nomeado aquêle conselho de re"gência para "o Govêrno dêstes Reinos", isto é, dos denominados reinos de Portugal e Algarves no próprio continente europeu.

Sempre fôra a administração ultramarina portuguêsa por demais precavida e esperta em seu cuidado de soberania ilimitada fora da metrópole continental, não esquecendo nunca das vantagens do velho axioma romano de "divide e impera", inclusive quanto às diversas ilhas ultramarinas e demais domínios coloniais. Enquanto o território brasileiro se manteve subdividido administrativamente, sem um govêrno central na Bahia ou no Rio de Janeiro, manter-se-ia de fato sob o domínio português metropolitano. Sòmente, depois, quando tal centralização surgida no Rio de Janeiro após a chegada da Côrte transmigrada de Lisboa, começaria a produzir seus frutos, é que marcharíamos para o desenlace público de nossa independência política e administrativa de 7 de setembro de 1822 !

$E$ ' que o nosso imenso território brasileiro, com seus núcleos esparsos e separados pela fatalidade geográfica local, nunca chegara a se constituir, até ao momento da chegada da Côrte ao Rio de Janeiro, em nada que se parecesse com uma unidade administrativa sujeita aos governadores-gerais da Bahia e, depois, aos vice-reis da futura capital monárquica aqui. Tanto os donatários iniciais como seus sucessores nas capitanias-gerais continuaram comunicando-se di-

(1). - Raul Brandão, El-Rei Junot. Livraria Brasileira de Monteiro \& Cia. Editôres, Lisboa, 1912: Pgs. 96 a 99. 
retamente com a metrópole, sem obrigatoriedade hierárquica de o fazerem por intermédio dêstes governadores-gerais ou dos vice-reis. Se estudássemos com cuidado aquela máquina governamental até 1808 , verificaríamos sempre que governadores-gerais e vice-reis apenas exerciam sôbre o todo o comando supremo militar em assuntos de defesa comum, bem como quanto à fiscalização fazendária sôbre a arrecadação dos impostos gerais, além de algumas poucas prerrogativas de caráter não-administrativo.

Poderes como aquêles concedidos ao operoso tenente-general Gomes Freire de Andrade (1685-1763), conde de Bobadela, desde o Espírito Santo até a Colônia do Sacramento e Mato Grosso, na chamada "Repartição do Sul", acumulando tôdas as atribuições administrativas, judiciárias, fazendárias e militares no Rio de Janeiro, ou mesmo como aquêles de 1774 a 1778 no extremo sul ao tenente-general João Henrique Boehm (1708-1783), alemão ao serviço real português no Brasil, como comandante-em-chefe luso-brasileiro e libertador da vila de Rio Grande em $1 .^{\circ}$ de abril de 1776 ao domínio temporário hispânico, constituem duas exceções únicas em tôda a nossa História. Da obra centralizadora pouco restaria após a sua morte no que diz respeito a Gomes Freire, mas na do tenente-general Boehm, graças à iniciativa do todo-poderoso ministro D. Sebastião José de Carvalho e Melo (1699-1872), conde de Oeiras e marquês de Pombal, ficaria no Brasil a organização de nosso primeiro exército verdadeiramente unificado quanto à sua hierarquia, instrução militar e disciplina. E' que Boehm viera despachado de Portugal para o Rio de Janeiro, com um grupo de oficiais portuguêses surgidos da escola reorganizadora do famoso chefe militar alemão marechal-general Frederico Guilherme von Schaumburg-Lippe (1724-1777), o conde de Lippe, como é mais conhecido em nossas tradições militares, tanto em Portugal como no Brasil.

Indicado pessoalmente pelo conde de Lippe ao marquês de Pombal, o tenente-general Boehm viera designado para exercer as funções e responsabilidade de inspetor-geral, como encarregado direto do comando e administração de todos os contingentes de infantaria, cavalaria e artilharia no então vice-reino nominal. Sua missão imediata seria a de normalizar e uniformizar a instrução militar que até então acompanhava sòmente aos caprichos e aos conhecimentos dos respectivos comandantes e, assim, introduzir também aqui as reformas implantadas em Portugal pela obra notável do já citado conde de Lippe. No Brasil tinha o novo inspetorsgeral por único superior hierárquico o próprio vice-rei do Rio de Janeiro, e assim mesmo naquilo que as decisões dêste não contrariassem à missão recebida diretamente da Côrte de Lisboa para aquêle. 
Nem Boehm, nem sua espôsa aqui chegados juntos em outubro de 1767 jamais deixariam o Brasil, para ambos verdadeira nova pátria, pois o casal falecera no Rio de Janeiro, ela cêrca de 1775 e êle em 22 de dezembro de 1783, sendo sepultado no Convento de Santo Antônio. Sua obra seria vivificada pelo transplante da Côrte portuguêsa ao Brasil, em 1808, quando se renovaria e se expandiria também pelas capitanias-gerais do Nordeste e do Norte brasileiro. A êle devemos, pois, as bases iniciais do nosso exército nacional brasileiro, como fator preponderante na obra de nossa unidade durante a vigência da monarquia imperial até 1889 , graças à personalidade do nosso marechal do Exército Luís Alves de Lima e Silva (1803-1880), o duque de Caxias, o grande pacificador do segundo reinado imperial. Histórica e cronològicamente seria aquêle aluno do conde de Lippe um dos predecessores, não só do nosso duque de Caxias, como do próprio marechal Hermes Rodrigues da Fonseca (1865-1923) no que diz respeito ao nosso exército como base auxiliar de nossa unidade nacional brasileira, obra continuada, no período entre as duas últimas conflagrações mundiais, pela benemérita Missão Militar Francesa entre nós.

Se unidade existia, esta apenas se firmava no. Brasil na subordinação mística comum a um mesmo soberano em Lisboa e à solidariedade natural conseqüente do parentesco consangüíneo entre seus povoadores, como resultado da irradiação das famílias principais dos dois centros demográficos iniciais nossos, os de Pernambuco-Bahia e de São Paulo-Rio de Janeiro, cujas estirpes entrelaçadas por múltiplos e constantes consórcios ainda hoje podem ser assimiladas em árvores genealógicas ou de costados de quase todos os brasileiros de Norte a Sul. Consangüínidade, linguajar comum, costumes religiosos e sociais semelhantes e subordinação ao mesmo rei, além de radicação a êste solo americano e os mesmos perigos frente à resistência inicial da indiada selvagem e à pirataria marítima, foram as únicas bases de unidade encontradas aqui pela Côrte em sua chegada em princípios de 1808 , bases profundas e poderosas, estimuladas pela incipiente organização militar já citada antes, pois do ponto de vista administrativo nunca existira outra unidade, nem mesmo aquelas propaladas depois pelo lirismo de nossos poetas.

Em tôrno de nosso maciço arqueano central e de seus contrafortes litorâneos todos os cursos fluviais, salvo raríssimos como o do rio São Francisco, facilitavam nossa dispersão demográfica e administrativa, isolando nossos centros povoadores de antanho. Nem nosas indiada constituia grupo único como argamassa consolidificadora desta unidade, pois se apresentavam numa variedade imensa de conglomerados de tribos rivais que se combatiam, que usavam linguajares os mais diversos, obrigando àquela aproximação lingüís- 
tica que fôra tentada pela catequese jesuítica com a criação de um verdadeiro "esperanto" brasílico, a chamada "língua geral", para facilitar um entendimento mais intenso de Norte a Sul.

Tais elementos telúricos favorecedores de uma dispersão demográfica e administrativa nossa, neutralizados apenas pelo espírito de uma solidariedade cujas raízes acabamos de citar, já haviam sido assinalados pelo nosso pioneiro da geo-política nacional, o grande e inesquecível Euclides da Cunha (1866-1909), o antigo aluno daquele tabernáculo científico que foi a Escola de Guerra da Praia Vermelha, no Rio de Janeiro, o autor de "Os Sertões", em sua última obra de geografia humana e de história pátria, editada após à sua trágica morte (2). Não deveríamos e nem podemos continuar acusando, assim, nossos primeiros povoadores, forçados a uma localização em nossa faixa litorânea, comprimidos que foram entre as muralhas da Serra do Mar e o Atlântico, como fundadores de uma civilização de "carangueijos". Que seria, talvez, de nossa atual unidade nacional se não recorressem aquêles nossos ancestrais e predecessores pátrios à única via de comunicações de que dispunham livremente, a do mar, para manter viva a solidariedade neste imenso território, neutralizando, assim, tudo o que os forçava à dispersão e ao isolamento?

Administrativamente existia ainda em 1808 no extremo Norte a criação daquele "Estado do Grão Pará", com a capitania subalterna do Rio Negro (atual Amazonas), e que surgira do "Estado do Maranhão" de 1621, com jurisdição exclusiva sôbre tôda a região amazônica e sempre separado do que restava do pretenso "Estado do Brasil". Bastaria isto para justificar porque no ato real de 26 de novembro de 1807, acima referido, citam-se apenas "os Estados da América" e nada dêste atualmente tão decantado "Estado do Brasil" que nunca passou de uma simples designação geográfica sem significado administrativo algum antes de janeiro de 1808, como significação puramente geográfica fôra a Itália de antes de $\mathbf{1 8 6 0}$ e a Alemanha de antes de 1871 .

Até então, como domínio ultramatino português sob monopólio mercantil proibitivo, não passava o nosso Brasil, pois, de um conglomerado de capitanias-generais que recebiam ordens régias diretamente do rei por intermédio do Conselho Ultramarino e que faziam suas próprias comunicações e davam suas respostas também diretamente pela mesma via administrativa ao soberano, sem submissão alguma às exigências das repartições dos vice-reis do Rio de Janeiro, salvo no judiciário, com exclusão da repartição da

(2). - Euclides da Cunha, À Margem da História. Livraria Chardron de Lello \&s Irmãos Editôres, Pôrto, 1909. Pgs. 258 e seguintes (em "Esbôço de história política: Da Independência à República). 
alçada da Bahia e do "Estado do Grão Pará", e em assuntos atinentes à organização do novo exército e à defesa militar geral. Assim, de fato e de direito, cada capitania-geral com suas capitanias subalternas já era como que um "estado" sujeito diretamente ao poder absoluto do rei, poder que desde 1808 passaria a ser exercido no Rio de Janeiro, como nova sede provisória da monarquia.

Pretender chamar o "Estado do Brasil" como designação oficial portuguêsa anterior à criação do Reino Unido de Portugal, Brasil e Algarves, não passa de afirmativa sem base jurídica alguma e muito menos histórica. Seria confundir intencionalmente o significado atual de tal termologia com usos e costumes do período monárquico absolutista de antanho. Mesmo atualmente o que se designa por "estado" nada mais é que a organização políticoadministrativa de um povo situado num território claramente delimitado. $\mathrm{Na}$ época em causa tais delimitações coincidiam com as de nossas capitanias-gerais com jurisdição sôbre as respectivas capitanias subalternas. Havia uma única coincidência designativa direta quanto ao já referido "Estado do Grão Pará". Até mesmo os nossos vice-reis nada mais eram senão verdadeiros capitães-generais do Rio de Janeiro e respectivas capitanias subalternas no Sul no que dizia respeito à administração, apesar de sua hierarquia nominal honorífica e de seu comando supremo puramente militar.

Desaparecido o que poderia ser admitido como autonomia administrativa e militar mais ampla interna nas antigas capitanias hereditárias, verdadeiras instituições de caráter feudal segundo os respectivos foros mesmo contrariando dispositivos supremos das "Ordenaçōes do Reino" no século XVI, tôdas já transformadas em capitanias-gerais por compra dos respectivos herdeiros, a administração do Brasil nunca passara de simples colônia de exploração mercantilista sob o domínio pessoal e absoluto "del-Rei de Portugal e dos Algarves daquém e dalém mar em Āfrica (Marrocos), Senhor de Guiné e da Conquista, da Navegação e do Comércio da Etiópia, da Arábia, da Pérsia e da Índia, etc.". Como todos os domínios ultramarinos de Portugal desde a éra dos descobrimentos, também o Brasil permaneceria sob o padroado espiritual e material do grão-mestrado da tradicional Ordem de Cristo, função incorporada à corôa desde o início do reinado de D. Manuel I, o Venturoso (1469-1521), a quem continuou pagando os impostos dos dízimos até pouco antes do regresso de D. João VI e de sua Côrte portuguêsa para Lisboa, em 1821. Nacionalizada esta ordem aqui, tais prerrogativas do padroado sòmente desapareciam com a abolição da nossa monarquia imperial em 1889 e conseqüente separação constitucional entre a Igreja e o Estado! 
O estatuto colonial que de direito e de fato vinha sendo mantido desde o seu descobrimento até ao decreto da Bahia, de 29 de janeiro de 1808, representado pela exploração das terras brasileiras segundo os princípios do chamado mercantilismo, da mesma maneira que tôdas as demais potências colonialistas, como a Espanha, a Inglaterra, a França e a Holanda, impondo à nossa gente aqui nascida e radicada tôda sorte de monopólios metropolitanos quanto so tráfego marítimo, tanto importador como exportador, nada tem a ver com esta ou aquela designação dada ao nosso Brasil, quer oficialmente em diplomas régios ou em obras literárias coevas. Continuamos simples colônia de exploração mercantilista, embora daqui e dali surgisse esta terra citada oficialmente, no todo ou em parte, como "Estado do Brasi1", ao lado de um "Estado do Maranhão" ou "Estado do Grão Pará" e alguns outros mais de caráter transitório. Chegamos a merecer de alguns cronistas o pornposo título de "Província do Brasil", numa extensão designatória haurida, talvez, de nossa primitiva "província jesuítica" brasileira, como também o rígido monarquista e genealogista paulista Pedro Taques de Almeida Paes Leme (1714-1777) em suas anotações contidas na famosa Nobiliarquia Paulistana, seguidamente se refere ao serviço da "república", mas não no sentido que iria ter após a vitória popular da Revolução Americana, de 1775 a 1783, implantando a primeira verdadeira república democrática e constitucional nos atuais Estados Unidos da América do Norte, embora tais palavras em nada modifiquem a evidência dos fatos. $O$ que realmente vale ante a História continuará sendo aquilo que de fato influi na vida particular e universal da nossa espécie, isto é, a realidade dos fatos, pois êstes precedem à palavra escrita impondothes o verdadeiro significado. Isolada da realidade, a palavra escrita não passa de letra morta sujeita à fantasia imaginativa de tôda sorte de especulações de tendências as mais variadas!

Tudo isto em nada alterou e nem altera quanto ao verdadeiro status internacional de colônia e domínio ultramarino, sempre em condições assemelháveis aos demais domínios portuguêses na África, na Índia, na China e na Malásia, onde se deparam hoje designações tais como de "Estado de Angola", "Estado de Moçambique", etc. Mesmo designado parcialmente como "Estado do Brasil" nos primeiros séculos, êstes "estados do Brasil" ou "êstes reinos" apenas vinham merecendo a inclusão no "etc." dos títulos oficiais dos soberanos portuguêses, "nossos amos e senhores", desde a descoberta até à sua elevação formal à categoria de parte integrante do "Reino Unido de Portugal, do Brasil e Algarves" em. 16 de dezembro de 1815 , a conselho e permissão das potências reunidas no fa- 
moso Congresso de Viena, reunido para tratar da organização da paz geral post-napoleônica.

Além de certas especulações de fundo saudosista ùltimamente surgidas em tôrno do emprêgo da designação de "Estado do Brasil", também outras bem mais patrióticas haviam surgido em tôrno de um tão decantado "Principado do Brasil", cuja existência jurídica ainda não foi comprovada, nem de fato e nem de direito. Pelo contrário, as cartas de lei, alvarás, etc. em tôrno da elevação do nosso Brasil à categoria hierárquica de reino unido, a começar pela carta de lei de 16 de dezembro de 1815 , firmada pelo ainda príncipe-regente $\mathrm{D}$. João, no Rio de Janeiro, apenas citam textualmente "os Estados que a Providência Divina confiou ao meu soberano regime", "os meus Reinos de Portugal e dos Algarves", "os meus domínios do Brasil", "o Estado do Brasil", sem nenhuma referência nem direta e nem indireta à existência reconhecida de um "Principado do Brasil", embora pessoalmente o futuro D. João VI usasse anteriormente seu título privativo de "Príncipe do Brasil".

$E^{\prime}$ que durante todo o domínio português e nem mesmo após a chegada da Côrte bragantina ao Rio de Janeiro, nunca apareceu o nosso Brasil oficialmente designado com tal dignidade hierárquica, atribuída alhures à então colônia ultramarina por certos historiadores nossos, notadamente quando julgam poder descrever uma fantasiosa "bandeira do Principado do Brasil" entre diversas outras pretensas "bandeiras históricas". Há nisto um grande eqüívoco de tais estudiosos, embora nenhum dêles se tenha preocupado em apresentar ato oficial algum elevando o Brasil à categoria hierárquica efetiva de "principado" e nem mesmo aquêle que, entre 1645 e 1647, teria dado ao pretenso "principado" como emblema heráldico a esfera armilar ultramarina privativa de D. Manuel I (3).

O que consta oficialmente em documentos portuguêses é única e exclusivamente a concessão feita em carta-patente de 27 de outubro de 1645, por D. João IV (1604-1656) ao infeliz Infảnte D. Teodósio de Bragança (1633-1653), então seu herdeiro primogênito e irmão dos futuros reis D. Afonso VI (1643-1683) e D. Pedro II (1648-1706), bem como a todos os futuros herdeiros primogênitos, da administração e uso pleno dos bens ancestrais alo. diais dos duques de Bragança e como "Príncipes do Brasil para o possuirem em título sòmente, e se chamarem Príncipes do Brasil e Duques de Bragança" (4). Estas disposições continuariam sem

(3). - Clovis Ribeiro, Brazōes e Bandeizas do Brasil. Com ilúlstrações de J. Washt Rođrigues. São Paulo Editôra Ltda., São Paulo, 1933. Pgs. 39 a 43

(4), - Francisco Adolpho Varnhagen, Visconde de Pôrto Seguro, História Geral do Brasil. 3a. edição integral. 3.0 tomo, de 1932. Pgs. 68 69 (Nota II, com texto integral da carta-patente). 
alterações até que o alvará régio de 9 de junho de 1817, estatuto regulador dos novos títulos privativos que competiam aos mesmos herdeiros primogênitos da corôa provisòriamente sediada no Rio de Janeiro, mencionando êste fato do "título de Príncipe do Brasil, para o possuirem em título, sòmente", e se chamassem "Príncipes do Brasil e Duques de Bragança", as substituiriam pelo novo título de "Príncipe Real do Reino Unido de Portugal, e do Brasil e Algarves, conservando-se o de Duque de Bragança" para os mesmos herdeiros primogênitos bragantinos.

A designação puramente geográfica de "Estado do Brasil", dada ao domínio português nesta colônia ultramarina, nunca fôra substituída, nem mesmo em caráter honorífico, por outra em documento algum antes de sua elevação formal a reino unido aos de Portugal e Algarves em dezembro de 1815. Nunca passara à categoria hierárquica de principado, nem de caráter feudal e nem soberano ou semi-soberano como alguns outros principados europeus da época. $\mathrm{Na}$ hierarquia portuguêsa, os únicos feudos efetivamente criados foram aquêles das nossas capitanias hereditárias, das nossas donatárias, embora parcialmente, como o comprovam os respectivos forais de concessão no Brasil e nas ilhas dos Açores e da Madeira. E' que desde a rebelião que instituira o reino independente de Portugal em 1139, tôda a nobreza fôra íntima e pessoalmente vinculada ao soberano legitimamente aceito e reconhecido e que surgira como poder supremo centralizador do antigo feudo castelhano portucalense. Só assim conseguira o reino fazer frente a tôdas as tentativas reabsorventes dos poderosos vizinhos de Castela e Leão.

Nestas condições, desde o comêço, os títulos nobiliárquicos portuguêses de duque, marquês, conde, visconde e barão, bem como o mais recente de príncipe, êste privativo dos antigos infantes reais ou filhos legítimos do soberano reinante, eram, sem exceção de nenhum dêles, apenas designações hierárquicas honoríficas, sem jurisdição territorial alguma. Um "Principado do Brasil" com soberania ou semi-soberania própria ou mesmo aparente, diretamente sujeito a um príncipe dêste mesmo predicado, o do Brasil, com que se pretende encobrir a nossa antiga situação de domínio colonial de exploração mercantilista sob monopólio estatal português, não passa, pois, de pura fantasia, como também não passa de outra fantasia de saudosismo sentimental, um "Estado do Brasil" com prerrogativas assemelhadas a uma província metropolitana de tipo mais moderno!

Mesmo assim há uma grande diferença entre estas duas designações fantasiosas, pois a única que poderia ser aplicada ao território inteiro pátrio seria a de "Principado do Brasil", se não se tratas- 
se de uma mera hipótese hierárquica. A outra, como "Estado do Brasil", nem mesmo serviria para tal, considerada segundo critérios concordantes com a realidade territorial nossa de antes da chegada da Côrte portuguêsa ao Rio de Janeiro, em 1808. Como expressão gecgráfica correta apenas serviria para designar como "Estado do Brasil", subdividido em suas duas alçadas ou repartições de então, a da Bahia e a do Rio de Janeiro, sòmente pouco mais da metade da superfície do nosso Brasil atual, isto é, cêrca de $4.440 .000 \mathrm{~km}^{2}$ desde o Rio Grande do Norte até ao arroio Chui e o Mato Grosso. Os restantes $4.060 .000 \mathrm{~km}^{2}$ caberiam aos territórios do "Estado do Maranhão" criado em 1621, incluindo o Ceará, e do depois "Estado do Grão Pará", inteiramente autônomos de tôda e qualquer jurisdição daquele pretenso "Estado do Brasil"!

Pelo mesmo motivo citado quanto ao sistema usual português em seus domínios ultramarinos não possuímos bandeira própria e nem privativa, já que não existíamos como "estado" e apenas como "estados" e capitanias-gerais. Tais símbolos de soberania, como atualmente estamos acostumados a ver e a usar com caráter nacional ou regional, surgiriam sòmente em 1790 , com a Revolução Francesa, copiadas daqueles que, daqui e dali, haviam sido arvoradas como representantes de nascentes soberanias populares anti-monárquicas nos Países-Baixos e nos Estados Unidos da América do Norte. Tanto em Portugal, como na Espanha, na França e em NápolesDuas Sicílias, a exemplo de tôdas as monarquias absolutistas da épo$\mathrm{ca}$, sòmente existiam como símbolos de soberania real e de domínio bandeiras que nada mais eram senão composições das próprias armas ou escudos das respectivas dinastias ou pessoais dos seus soberanos reinantes. Assim, sôbre o pano branco das bandeiras reais de Portugal, da Epanha, da França e de Nápoles-Duas Sicílias, tremulavam as armas oficialmente usadas pelos respectivos soberanos, com as variações decorrentes apenas do desênho das côres ou de alguns ornatos exteriores secundários. O branco era tradicional desde antes da dinastia de Aviz em Portugal, usado na Espanha dos Áustrias ou Habsburgos e dos Bourbons-Anjou seus sucessores, bem como, segundo velho símbolo bourbônico na França até 1790 e em Nápoles-Duas Sicílias até 1860.

Foi para evitar as naturais confusões no mar que os soberanos hispânicos haviam substituído, desde 1785 , o branco pelo amarelo com duas listas vermelhas horizontais, as mesmas côres nacionais mantidas até ao presente. No tricolor de 1790 , surgida como símbolo popular parisiense com a Revolução Francesa, manteve-se o branco no centro, da mesma maneira como se manteria na tricolor italiana de 1797 e que passaria à tricolor nacional com o movimento unificador iniciado em 1848. 
Entre nós, no Brasil, manter-se-ia tal bandeira real branca com as armas portuguêsas, embora acrescidas da esfera armilar em virtude do decreto de 13 de maio de 1816 que criou as armas do novo Reino Unido de Portugal, Brasil e Algarves, até a reforma imposta pela vitória liberal e constitucional de 1820 na metrópole européia. Mesmo nesta ficaria o branco ao lado do antigo azul de 1640, bandeira monárquica portuguêsa que sòmente desapareceria em 1910 com a proclamação definitiva da República Portuguêsa e com a sua nova bandeira, a atual. Nesta reapareceria a esfera armilar abolida na de 1821, símbolo clássico do ultramar português e que fôra criado por D. João II, o Príncipe Perfeito (1455-1495), para seu sobrinho e sucessor, o já citado e depois D. Manuel I o Venturoso, (1469-1521), o primeiro que de fato reinaria sôbre o Brasil recémdescoberto, quando ainda herdeiro e para uso em caráter puramente pessoal, como grão-mestre da Ordem de Cristo.

Assim, mesmo naqueles tempos era uma só a bandeira real, verdadeiro pendão de soberania pessoal usada como hoje se usam os pavilhões presidenciais entre nós. A partir de 1495, ao subir ao trono português, o mesmo $\mathrm{D}$. Manuel I deixaria de ostentar sua bandeira pessoal com a esfera armilar, substituindo-a pela de soberano com as armas reais no pano branco, sobrepondo-as apenas ao símbolo da Ordem de Cristo, da qual continuou sendo seu grão-mestre. Como símbolo corrente da soberania real portuguêsa de então, surgem nos desenhos das cartas geográficas o chamado pendão ou bandeira das quinas, com os cinco besantes de prata sôbre o pano azul de tonalidade quase celeste. O capitão-mor Pedro Álvares $\mathrm{Ca}$ bral (1460-1526) levara em sua viagem às Indias, na qual descobriria o rosso Brasil, uma bandeira da Ordem de Cristo e não o pendão real de soberania. Foi esta bandeira da Ordem de Cristo que, segundo consta oficialmente na famosa carta de Pero Vaz de Caminha, seria arvorada em terras brasileiras em 1500 , no ato da tomada de posse e da' primeira missa aqui então celebrada.

Bandeiras, estandartes e bandeirolas particulares, tôdas sem significado de soberania, mas apenas usadas como símbolos pessoais de fidalgos poderosos ou como simples cortesia, homenagem ou individualização de unidades maritimas, deveriam ter aparecido nos mastros dos navios armados em guerra ou simplesmente de comércio desde os tempos da descoberta e do início da conquista e do povoamento, a começar pelo pendão da Ordem de Cristo e pelo das chamadas quinas portuguêsas. Depois, entre 1618 e 1640, para diferenciar os navios destinados ao Brasil dos demais hispânicos pròpriamente ditos, usaram-se bandeiras com a cor branca fundamental trocada pelo vermelho ou pelo azul, embora sempre com as armas reais portuguêsas. Tais diferenças também se usariam após o cha- 
mado domínio espanhol, entre 1640 e 1668, nas lutas da Restauração de Portugal, com orlas azuis sôbre o branco fundamental ou com o pano todo de verde, esta oficialmente no reinado de D. Pedro II, já citado. Naquelas lutas aparecem outras bandeiras regimentais ou de agrupamentos de combate com o pano também de verde e com a cruz da Ordem de Cristo, para melhor diferenciação das unidades hispânicas em guerra.

Foi na fase final das nossas lutas brasílicas contra o domínio holandês em tôrno de Pernambuco que surgiria a chamada Companhia Geral do Comércio para o Brasil, fundada por alvará régio de 6 de fevereiro de 1649, com estatutos de 8 de março do mesmo ano, com participação compulsória de capitais judaicos, recebendo como insígnia a mesma esfera armilar ultramarina já mencionada. Esta Companhia Geral de Comércio teria monopólio absoluto e exclusivo, com imunidades e privilégios imensos e que passariam, corn seus verdadeiros tribunais despóticos, a explorar o tráfego marítimo com o Brasil e o seu fornecimento de muitos gêneros e utensílios, sem sujeição alguma às autoridades ultramarinas portuguêsas daqui. Teria por duração 20 anos, prorrogáveis por mais 10, e suas atividades bastariam por si só para comprovar a implantação odiosa de um regime colonialista super-mencantilista no pretenso "Estado do Brasil". Com o tempo, graças aos movimentos de rebeldia por ela provocadas no Maranhão e noutros pontos da colônia, bem como das múltiplas representaçóes feitas ao soberano contra o despotismo mercantilista trazido pela mesma. foram seus privilégios se restringindo, transformando-a num simples tribunal régio, extinto, finalmente, em 1720 .

Atribui-se a esta odiosa Companhia Geral do Comércio para o Brasil, cujos benefícios apenas serviram para premiar representantes da fidalguia portuguêsa na metrópole e alguns ricaços de lá, a divulgação de um pavilhão comercial privilegiado ostentando sua esfera armilar de ouro ou amarelo sôbre pano branco, como se êste pavilhão eqüivalente aos atualmente usados pelas companhias ou emprêsas de navegação comercial nacionais e estrangeiras, como o do nosso Lóide Brasileiro, fôsse eqüivalente a uma bandeira histórica brasileira pròpriamente dita, inclusive daquele hipotético e fantasioso "Principado do Brasil". Citam-se também, daqui e dali, outras bandeiras ou pavilhões de pano branco, tendo no centro ou num dos cantos aquela mesma esfera armilar que a tradição pretende afirmar tenha sido um emblema indicativo do Brasil, sem outro comprovante senão o acima citado pavilhão mercante e outros que teriam sido usados entre os séculos XVII e XVIII, como "bandeira para a India e América", tôdas comerciais e não de soberania. 
Convém frisar que aquela esfera armilar nunca se constituira como de uso privativo brasileiro naqueles tempos do domínio português, embora aparecesse em algumas moedas batidas no Brasil em 1694 para uso corrente em Pernambuco, Rio de Janeiro e Bahia, pois figura também desde 1512 nas moedas batidas em Málaca e noutros domínios ultramarinos asiáticos, nos escudos e brazões de diversas cidades metropolitanas e até na concedida ao Rio: de Janeiro em 1565, sôbre as tradicionais 3 setas. E' bem possível que exatamente êste brazão municipal carioca de 1565 tenha influído poderosamente para o seu emprêgo heráldico como peculiar brasileiro na bandeira do depois Reino Unido de Portugal, Brasil e Algarves, juntamente com o azul de tonalidade celeste que figurava no primeiro brazão local da cidade do Salvador, na Bahia.

Enquanto se restringia o uso da bandeira branca que representava a unidade da soberania real da casa de Bragança, diferente apenas da de sua ríval hispânica quanto ao brasão real português, aos navios de guerra e sôbre as muralhas das praças fortes aqui no Brasil, difundira-se também bandeiras e pendões particulares nos regimentos pagos e terços de homens de armas diferentes daquela. Assim, nenhum agrupamento de combate dos patriotas pernambucanos em luta contra os dominadores holandeses do Nordeste usaria a bandeira real privativa da própria corôa metropolitana. Seus pendões se apresentavam mais como símbolos de mística religiosa católica ancestral. Nas famosas entradas dos sertanistas paulistas, os bandeirantes, sòmente se arvoraram pendões particulares escolhidos livremente por seus chefes, jamais usando bandeiras portuguêsas das quinas ou aquela privativa de seu soberano, uma vez que tais empreendimentos sempre se apresentavam como particulares, muitos até contrariando ordens régias ou das autoridades supremas coloniais ou locais.

Em nossas lutas contra os castelhanos no Sul e no Mato Grosso, depois de 1680 , apareceriam por aqui bandeiras e pendões par-ticulares para cada regimento ou unidade de combate, uso generalizado em Portugal com o chamado domínio espanhol. Desde então haviam adotado todos os regimentos ou terços portuguêses seus: estandartes ou bandeiras privativas a princípio com a cruz da Ordem de Cristo e depois com desenhos geométricos variadíssimos sô-. bre esquartelados em cruz e em aspa e com bordaduras, combinando as côres distintivas da Casa Real bragantina, azul e vermelho, com amarelo e branco ou outras côres de seus uniformes. Tais usos, tìpicamente franceses com seus retângulos e triângulos de côres diferentes e combinações as mais variadas para cada unidade, manter-se-iam até ao regresso de $\mathbf{D}$. João VI e de sua Côrtepara Lisboa. 
As citadas côres azul e vermelho, designadas como distintivos da Casa Real bragantina, eram apenas as côres palatinas e não as heráldicas da dinastia português reinante desde 1640. Naqueles tempos, quando não existiam nem módulos rígidos para a feitura de bandeiras, estandartes e pendões, situação que perdurou até mesmo entre nós durante tôda a monarquia imperial, as côres regimentais e de seus estandartes nada tinham de comum com a bandeira real. Estas côres, caracterizadas nos respectivos topes militares ou laços distintivos, fixadas nos chapéus e barretinas, geralmente de duas, três ou mais côres, tiradas estas ou das côres do uniforme ou dos librés particulares de seus coronéis comandantes, ao menos até 1707. A partir daí generalizara-se também em Portugal como tope distintivo um laço prêto, segundo a moda inglêsa da época, até que pelo decreto régio de 7 de janeiro de 1796, se determinaria sua mudança obrigatória para o único com as côres azul e vermelho, acima citadas, que eram as dos librés dos servidores palatinos da Casa Real, significando, com tal ato, que tôdas as unidades militares portuguêsas se achavam a serviço pessoal do soberano e de sua Casa Real.

Mesmo conservando as bandeiras e estandartes existentes antes, não manteriam as Côrtes Gerais Extraordinárias e Constituintes de Lisboa, após a derrogação do regime absolutista em 1820, aquêle tope militar de 1796, substituindo-o pelo novo laço nacional português de côres azul e branco, segundo carta de lei de 23 de agôsto de 1821, mandada cumprir no Brasil, por ordem de seu príncipe-regente, o futuro imperador D. Pedro I (1798-1834), de acôrdo com o decreto n. 70 , de 31 de outubro de 1821. Seriam êstes mesmos laços azul e branco os que o mesmo príncipe-regente mandaria arrancar em 7 de setembro de 1822 , ao proclamar pùblicamente nossa independência junto ao Ipiranga, em São Paulo.

Caberia à Revolução Francesa o emprêgo inicial generalizado de uma mesma bandeira, a tricolor revolucionária de 1790, como símbolo único da soberania popular e da nação indivisível, tanto como bandeira nacional, como militar e maritima. As diferenciações admissíveis seriam apenas as inscrições indicativas das unidades militares, das repartições públicas, etc., bem como alguns emblemas privativos sobrepostos ou bordados às bandeiras. A Inglaterra manteve um sistema mais regular, codificando a tradição com os novos usos, isto é, dando a cada batalhão ou unidade correspondente de suas fôrças armadas sempre duas bandeiras, sendo a principal a do rei como nacional, ao lado da privativa que simbolizavo cada unidade e na qual se sobrepunham os dísticos e honrarias.

Com a nossa independência, a monarquia imperial brasileira passaria a adotar aquêles usos da França revolucionária quanto à 
bandeira única em todo o país, abolindo tôdas as anteriores em nossos regimentos e batalhões. $O$ interessante é que caberia exatamente à República, após a vitória da chamada Revolução Nacional de 1930, atualmente tão malsinada, restabelecer aquela antiqüíssima tradição, concedendo, a partir de 1931, novos estandartes privativos para as nossas fôrças armadas, de uso obrigatório à esquerda das respectivas bandeiras nacionais brasileiras (5).

Assim, subdividido administrativamente em múltiplos "estados" ou capitanias-gerais, sem bandeira ou outra insígnia geral própria, nem mesmo com estandartes militares idênticos em seu exército ultramarino português que influissem como elemento auxiliar unificador em nossa pátria durante a monarquia absolutista bragantina, sem levar em conta a mística da obediência natural ao "nosso amo e senhor" provisòrimente estabelecido no Rio de Janeiro, dificilmente teríamos em 1822 um Brasil unido e livre, constitucionalmente organizado e preparado para assumir em 1889 seu posto entre as democracias americanas. Sem aquela mística transferida em 1808 para sua sede provisória no Rio de Janeiro, não seríamos o que somos, nem teríamos nossa atual extensão territorial, bem maior que aquela do pretenso "Estado do Brasil" de antanho!

HENRIQUE OSCAR WIEDERSPAHN Ten.-Cel. Dos Institutos Históricos e Geográficos do Pará, de São Paulo e do Rio Grande do Sul, do Instituto Genealógico Brasileiro, do Colégio de Armas e Consulta Heráldica do Brasil, etc.

(5). - Clovis Ribeiro, Brazões e Bandeiras do Brasil. Obra já citada e que, embora, com certas reservas, continua sendo básica; Gilbert Grosvenor e William J. Showalter, Flags of the World. Em "The National Geographic Magazine" editado pela "National Geographic Society" de Washington D. C., U.S.A. Vol. LXVI. N.0 3, setembro de 1834. Pgs. 339 a 396; Ottfried Neubecker, $F$ ahnen und Flaggen. Eine bunte Fibel. - L. Staackmann Verlag, Leipzig, 1939. 